\title{
Konstruksi Budaya Anak Muda pada Novel Populer Indonesia Tahun 2000-an
}

\author{
Muhamad Adji \\ Departemen Susastra dan Kajian Budaya \\ Fakultas Ilmu Budaya, Universitas Padjadjaran \\ Jalan Raya Bandung Sumedang Km.21 Jatinangor, Sumedang 45363 \\ Email:m.adji@unpad.ac.id
}

\begin{abstract}
Current development of theory, especially in the field of cultural studies, shows that popular novel texts can be studied with various approaches, not only focused on aesthetic aspects. This research was conducted as an effort to find the cultural construction in the popular novels of the 2000s. This research uses an interdisciplinary approach that involves various concepts in the field of cultural studies, such as discourse, ideology, class, and post-colonial. The method used is a textual analisys. The data sources of this study are three popular novels published in the 2000s, namely Ayat-Ayat Cinta by Habiburrahman El-Shirazi (2004), Sang Pemimpi by Andrea Hirata (2005), and Negeri 5 Menara by Ahmad Fuadi (2009). The results of this study indicate that in popular novels in the 2000s, the dream of changing class through education became the dominant discourse, and young people who were constructed as dreamers were young people from the periphery class. This brings to a conclusion that the popular novels of the 2000s offered the construction of young people from different social group that differ from the mainstream construction of popular novels that usually came from the upper-middle class.
\end{abstract}

Keywords: popular novel, youth, cultural studies, changing theme

\begin{abstract}
ABSTRAK
Perkembangan teori terkini, terutama dalam bidang kajian budaya menunjukkan bahwa teks novel populer dapat dipelajari dengan berbagai pendekatan, tidak hanya fokus pada aspek estetika. Penelitian ini dilakukan dalam upaya untuk menemukan adanya konstruksi budaya pada novel populer tahun 2000-an. Penelitian ini menggunakan pendekatan interdisipliner yang melibatkan berbagai konsep dalam bidang kajian budaya, seperti wacana, ideologi, kelas, dan post-kolonial. Metode yang digunakan adalah studi teks. Sumber data penelitian ini adalah tiga novel populer yang terbit pada tahun 2000-an, yaitu Ayat-Ayat Cinta karya Habiburrahman El-Syirazi (2004), Sang Pemimpi karya Andrea Hirata (2005), dan Negeri 5 Menara karya Ahmad Fuadi (2009). Hasil penelitian ini menunjukkan bahwa dalam novel populer tahun 2000-an, impian perubahan kelas melalui pendidikan menjadi wacana dominan, dan anak muda yang dikonstruksikan sebagai pembawa impian tersebut adalah anak muda yang berasal dari kelas pinggiran. Hal ini memberi kesimpulan bahwa novel populer tahun 2000-an menawarkan konstruksi anak muda yang berbeda yang keluar dari konstruksi arus utama novel populer yang biasanya berasal dari kelas menengah atas.
\end{abstract}

Kata kunci: novel populer, anak muda, kajian budaya, perubahan tema 


\section{PENDAHULUAN}

Sastra merupakan sebuah potret sosial yang menyajikan kembali realitas masyarakat yang pernah terjadi dengan cara yang khas sesuai dengan penafsiran dan ideologi pengarangnya. Pengertian sastra tidak hanya sekadar tiruan atas realitas seperti yang diungkapkan oleh Plato (Teeuw, 2003: 181), tetapi perpaduan antara rekaman realitas dan kreasi (creatio) atas realitas tersebut, seperti yang diungkapkan oleh Aristoteles (dalam Teeuw. 2003: 182). Dengan demikian, mengacu pada pandangan Aristoteles tersebut, sastra adalah "realitas baru" yang bertitik tolak pada realitas sosial budaya yang dimediasi oleh pengarang.

Sebagai bagian dari masyarakat, pengarang juga tidak dapat dipisahkan dari struktur sosial yang melingkupinya. Artinya, seberapapun jauhnya hubungan "realitas teks" dari realitas sosial yang sesungguhnya, hal itu tetap dapat ditarik pada realitas sosial budaya yang terjadi saat karya sastra itu lahir. Dengan kata lain, latar belakang sosial budaya pengarang serta dinamika sosial kultural yang terjadi pada masa itu turut memengaruhi pengarang dalam menyikapi relitas sosial yang terwujud pada karya sastra yang dihasilkannya.

Sebagai produk budaya massa, novel populer tidak terlepas dari berbagai konteks yang ada karena fenomena budaya selalu terhubung dengan ranah-ranah yang lain: agama, sosial, politik, ekonomi, kekuasaan, pendidikan, bahasa, dan lain-lain. Dengan mengetengahkan kehidupan anak muda yang memiliki sifat dinamis, novel populer menjadi teks yang sangat strategis sebagai area perebutan wacana dan nilai-nilai. Oleh karena itu, penelitian terhadap novel populer menjadi kajian yang penting dilakukan untuk melihat bagaimana teks novel populer tersebut berhubungan saling silang dengan latar belakang pengarang, nilai-nilai yang dianut pengarang, dan nilai-nilai dalam masyarakat, serta medan sosial yang dihadapi.
Dalam kaitannya sebagai teks sastra, novel populer pada umumnya dilihat dalam konteks estetika yang dibangun dari perspektif modernisme. Oleh karena itu, dalam konteks tersebut, novel populer cenderung dipahami dalam pengertian estetika modern. Estetika modern mengklasifikasikan seni ke dalam dua bentuk, yaitu seni high art dan low art. Novel yang diklasifikasikan ke dalam seni low art adalah seni yang dianggap memiliki nilai estetik yang rendah, sebagai perbandingan dengan sastra serius yang memiliki kualitas estetik yang adiluhung. Secara filosofis, menurut Piliang (dalam Hanif dan Piliang, 2015: 326), pertentangan antara seni tinggi (high art) dengan budaya massa (low art) adalah refleksi dari pertarungan pemikiran antara tokoh-tokoh modernisme puritan, yaitu Hegel, berhadapan dengan tokoh-tokoh post-modernisme awal terutama Nietszche dan Heidegger.

Modernisme berangkat dari konsep oposisi biner, yang jika ditelusuri sejarahnya, berangkat dari paham rasionalisme Rene Descastes. Rasionalisme menyatakan bahwa sumber pengetahuan manusia adalah akal atau rasio (Adian, 2002: 44). Sebagai sumber pengetahuan, rasio dianggap memiliki otoritas untuk menentukan kebenaran, terutama dalam pertentangannya dengan empirisme yang dianggap sebagai sumber pengetahuan yang tidak memiliki landasan yang kokoh bagi ilmu pengetahuan. Dalam perkembangannya, rasionalisme dipertentangkan dengan pertimbangan yang berdasarkan perasaan, tahayul, dan iman (Adian, 2002: 44). Sesuatu yang tidak mengikuti pola-pola rasionalitas akan dikategorikan pada sesuatu yang lebih rendah sebagai oposisi dari rasionalitas karena rasionalitas membutuhkan suatu kondisi ketika terdapat proses negasi atau bahkan "melupakan" terhadap spirit yang berupa alam bawah sadar (mitos) sebagai proyek penyempurnaan dirinya (Piliang, 1999: 22). 
Dalam kategorisasi di atas, novel populer dimitoskan ke dalam novel yang bercirikan tidak mengusung kebernalaran manusia, misalnya akhir cerita yang mudah ditebak, adanya faktor serba kebetulan, tokohnya bersifat stereotipe dan cenderung tidak berkembang, temanya dangkal, dan sebagainya, sehingga banyak dibaca oleh kalangan awam. Novel serius memiliki ciri-ciri yang berkebalikan dari novel populer dan biasanya dibaca oleh pembaca intelek. Kategorisasi ini sebenarnya merupakan generalisasi sehingga keabsahannya perlu untuk dikaji ulang. Cara pandang ini menyebabkan sastra di luar kategori itu, seperti sastra populer, dianggap bukan sastra dan terabaikan dalam kajian-kajian sastra. Bourdieu (dalam Herwanto, 2005: 182) juga mengkritisi pandangan bahwa estetika dibangun dari kriteria objektif tentang baik dan buruk sehingga memunculkan karya yang high culture dan karya yang low culture. Menurut Bourdieu, penentuan cita rasa estetik itu ditentukan secara sosial (Herwanto, 2005: 182). Di Indonesia, seperti yang disinyalir Heryanto (dalam Sen, 2001: 28), kode-kode estetik itu ditentukan secara historis oleh lembaga-lembaga kebudayaan untuk menentukan mana yang termasuk sastra "tinggi" dan mana yang termasuk ke dalam sastra "rendah" atau yang dikenal dengan istilah sastra populer.

Sebagai bentuk respon atas modernisme, postmodernisme menawarkan sesuatu konsep berpikir yang baru. Menurut Foucault, postmodernisme merupakan antitesis pola rasionalitas cogito ergo sum Cartesian (Ratna, 2007: 28), karena dalam semangat Cartesian rasionalitas menjadi ukuran tunggal kebenaran (Piliang, 2003: 73). Postmodernisme ingin memberikan tempat bagi berbagai bentuk wacana yang berbeda, sebab banyak jalan menuju pengetahuan, tidak hanya bersifat rasional (O'Donnel, 2009: 22).

Keberagaman dalam perspektif postmodernisme dirayakan sehingga mengaki- batkan tidak adanya pusat logos (O'Donnel, 2009: 15). Dengan perspektif tersebut, novel populer diletakkan dalam posisi yang sejajar dengan novel serius sebagai teks yang berharga untuk diteliti karena merupakan produk budaya. Sejalan dengan itu, Faruk menyatakan bahwa cultural studies atau kajian budaya menempatkan karya-karya sastra populer sebagai objek kajian yang sama berharganya dengan karya-karya sastra yang dianggap tinggi dan serius (2012: 73). Bagi cultural studies, setiap teks budaya memiliki caranya sendiri untuk mengartikulasikan diri dan untuk dipahami. Dengan demikian, pengkajian terhadap novel populer menjadi sahih untuk dilakukan karena cultural studies memberikan ruang gerak yang luas bagi kajian-kajian terhadap teks budaya seperti novel populer dengan melepaskan beban estetika pada teks tersebut.

Tulisan ini akan menguraikan kontruksi budaya anak muda yang direpresentasikan pada novel populer Indonesia. Sumber data dalam tulisan ini adalah Sang Pemimpi karya Andrea Hirata (Bentang Pustaka, 2005), Negeri Lima Menara karya Ahmad Fuadi (Gramedia Pustaka Utama, 2009), dan AyatAyat Cinta karya Habiburrahman El-Syirazi (Republika Press, 2004). Ketiga novel tersebut dipilih karena memiliki tingkat apresiasi yang tinggi dari pembaca yang ditandai de-ngan jumlah terbitan yang sangat tinggi (best seller). Novel Ayat-Ayat Cinta, sejak diterbitkan pada tahun 2004, telah mencapai cetak ulang sebanyak 500 ribu kopi pada tahun 2007. Kesuksesan novel ini dilanjutkan melalui filmnya yang mencapai jumlah 3,8 juta penonton. Novel Sang Pemimpi juga masuk ke dalam kategori best seller dan juga telah diangkat ke layar film dengan jumlah penonton mencapai 1,9 juta. Begitu pula dengan novel Negeri 5 Menara yang juga masuk dalam kategori best seller dan telah diangkat ke layar film dengan apresiasi penonton yang kurang lebih sama dengan kedua novel yang disebutkan sebelumnya. 


\section{METODE}

Penelitian ini merupakan penelitian kualitatif dengan menggunakan pendekatan kajian budaya. Tujuannya, untuk memahami suatu teks budaya secara eklektik dengan memberi ruang yang terbuka bagi berbagai teori untuk digunakan dalam proses tersebut. Kajian budaya merupakan arena yang terbuka luas bagi berbagai bentuk penafsiran terhadap teks budaya. Hal ini dikuatkan dengan pernyataan Barker, seperti dikutip Iskandar dkk. (2015: 312), yang menyatakan bahwa kajian budaya adalah sekumpulan atau formasi gagasan, citra, dan praktik yang menyediakan cara-cara untuk berbicara tentang menyediakan bentuk-bentuk pengetahuan dan tingkah laku yang diasosiasikan dengan suatu topik, aktivitas sosial atau wilayah institusional tertentu dalam masyarakat. Agger juga menjelaskan bahwa kajian budaya menunjukkan keterlibatan ideologi dalam kebudayaan sehingga kebudayaan dikondisikan sebagai memiliki ciriciri partisipan, bahkan memihak (Iskandar dkk., 2015: 312). Dengan demikian, dapat disimpulkan bahwa penafsiran dengan menggunakan kajian budaya cenderung ideologis meskipun tetap menggunakan tahapan-tahapan objektif seperti yang dilakukan dalam metode semiotika. Jika dirunut ke belakang, semiotika yang digunakan dalam bidang kajian budaya mengadopsi metode struktural yang bersumber dari ranah dan pelopor yang sama, yakni ahli linguistik struktural Ferdinand de Saussure (1857-1913) (Saidi, 2008: 39).

Dalam menemukan kontruksi budaya anak muda yang terkandung di dalam teks, digunakan metode analisis isi dengan beberapa tahapan. Pertama, pembacaan mendalam (close reading) terhadap isi teks. Kedua, mengaitkan pembacaan teks dengan pendekatan kajian budaya sebagai upaya untuk mendapatkan pemahaman mendalam tentang kontruksi budaya anak muda pada tahun 2000-an.

\section{HASIL DAN PEMBAHASAN}

\section{Impian Perubahan Kelas sebagai Wacana Dominan}

Pada novel-novel populer tahun 2000an, impian adalah wacana yang dominan. Impian yang dibangun di dalam teks novel populer pada umumnya berupa impian untuk naik ke kelas yang lebih tinggi, dan untuk mencapainya adalah melalui jalur pendidikan. Bila dibandingkan dengan novel-novel populer pada era sebelumnya, tampak jelas perbedaan wacana yang dikembangkan di dalam teks. Wacana novel populer tahun '70-an yang berkembang adalah persoalan percintaan. Dinyatakan Sumardjo (1980: 19), wacana percintaan anak muda ini biasanya ditulis oleh pengarang laki-laki yang isinya mengisahkan masa-masa pacaran. Sedangkan wacana percintaan yang ditulis oleh penulis perempuan biasanya berkisar pada masa pacaran sampai ke hubungan pernikahan dan problematika kehidupan rumah tangga. Pada periode 1980-1990-an, wacana yang berkembang masih berkisar pada kehidupan anak muda dengan problematika percintaan. Tokoh yang diangkat adalah anak muda dari kalangan menengah ke atas dan berasal dari wilayah pusat sehingga upaya mobilitas ke atas tidak muncul dalam wacana novel populer periode ini. Dengan demikian, terjadi perkembangan wacana pada sastra populer periode 2000 -an jika kita bandingkan dengan dua periode sebelumnya.

Jika dirunut pada aspek biografis pengarang, dapat disimpulkan bahwa masa muda ketiga pengarang tersebut di atas dilewati dalam dua masa, yaitu masa Orde Baru dan masa Pasca-Orde Baru. Sebagai novel yang dapat dikategorikan sebagai novel biografis, kisah tersebut adalah kisah tokoh anak muda yang dibangun pada masa Orde Baru. Kisah yang menunjukkan besarnya keinginan golongan muda dari kelompok masyarakat kelas tertentu untuk melakukan mobilitas vertikal, dari kelas bawah pinggiran tradisional naik ke 
wilayah kelas menengah modern melalui jalur pendidikan.

Novel populer berupa kisah biografis yang bertemakan impian tersebut menemukan momentumnya pada masa pascaOrde Baru ketika masyarakat Indonesia sedang berupaya bangkit kembali dari krisis ekonomi politik dan harapan akan keterbukaan aspek sosial-politik-budaya. Hal ini pula tampaknya yang menyebabkan tematema impian dengan latar belakang yang beragam warna lokalnya menjadi diterima oleh masyarakat pembaca Indonesia dengan antusias.

Impian tokoh menjadi nilai-nilai dominan di dalam novel populer tahun 2000-an. Hal itu setidaknya dapat dilihat beberapa hal. Pertama, dilihat dari penceritaan. Kedua, dilihat dari strategi teks yang mewacanakan impian melalui pandangan narator dan tokoh lainnya. Dilihat dari penceritaan, dapat dilihat bahwa impianimpian tersebut dibangun oleh teks dengan menunjukkan efek yang membangun dan menghambat kesungguhan para tokoh untuk meraih impian tersebut. Impian yang dibangun sejak awal sampai akhir di dalam cerita merupakan strategi pengarang sebagai upaya menjadikannya sebagai wacana dominan dalam teks. Hal itu terlihat pada beberapa novel yang dianalisis dalam tulisan ini, sebagai berikut.

Pada novel Sang Pemimpi karya Andrea Hirata (2005), Ikal memperlihatkan bahwa sejak awal, ia telah menunjukkan keinginannya untuk mengecap sekolah ke luar negeri. Pilihannya adalah pendidikan yang lahir dari peradaban Barat, sebagaimana tertulis dalam kutipan berikut.

Pada saat itulah, aku, Arai, dan Jimbron mengikrarkan satu harapan yang ambisius: kami ingin dan harus sekolah ke Prancis! Ingin menginjakkan kaki di altar suci almamater Sorbonne, ingin menjelajah Eropa sampai ke Afrika. Begitu tinggi cita-cita itu (Hirata, 2005: 62).

Yang menarik adalah bahwa sejak awal
Ikal bersama Arai dan Jimbron, kedua sahabatnya, meneguhkan keinginan mereka untuk bersekolah di Univerisitas Sorbonne, Prancis. Sementara itu, tidak ada bagian teks yang mendukung bagaimana mereka mengetahui keunggulan Universitas Sorbonne, yang diakui sebagai salah satu universitas terbaik dunia. Dengan latar belakang kota yang jauh dari akses informasi, agak sulit dipahami dengan nalar bahwa mereka mengetahui dan memahami dengan baik informasi yang berkaitan dengan universitas terbaik di dunia. Dengan demikian, pada bagian ini, pengarang masuk sebagai narator dan menggantikan tokoh aku lirik. Latar belakang Andrea Hirata yang pernah melanjutkan studi di Universitas Sorbonne, Paris, memberikan dasar bahwa pengarang mengenal dengan sangat baik Paris yang dianggap sebagai pusat peradaban dunia. Dengan demikian, Andrea Hirata meminjam tokoh cerita untuk menggambarkan supremasi Eropa sebagai sumber peradaban dunia.

Hal ini menunjukkan bahwa perspektif pendidikan yang dibangun di dalam novel populer, yang direpresentasikan oleh tokoh Ikal dan guru-guru Ikal, masih berkiblat pada pandangan kolonialisme bahwa ilmu pengetahuan dan peradaban tertinggi masih merujuk pada peradaban Barat. Tesis ini juga dibuktikan dengan penggambaran yang bersifat oposisi biner: masyarakat lokal Belitung yang miskin, belum maju, yang pemikirannya belum tercerahkan, dan masih menggunakan cara berpikir pendek, yang merepresentasikan peradaban Timur sebagai bentuk kontradiktif terhadap peradaban Barat. Pesan tersebut menjadi narasi besar dalam cerita yang membungkus alur cerita sampai pada ending cerita.

Pada novel Negeri 5 Menara karya Ahmad Fuadi (2009), impian untuk merasakan pendidikan di luar negeri diawali tokoh Alif melalui kegiatan membangun anganangannya yang acap dilakukan bersama 
teman-temannya di bawah menara masjid. Hal itu sebagaimana digambarkan dalam kutipan di bawah ini.

Di bawah bayangan menara ini kami lewatkan waktu untuk bercerita tentang impianimpian kami, membahas pelajaran tadi siang, ditemani kacang sukro. Bagaikan menara, cita-cita kami tinggi menjulang. Kami ingin sampai di puncak-puncak mimpi kami kelak (Fuadi, 2009: 94).

Dibandingkan dengan novel Sang Pemimpi, impian yang dibangun di pada novel Negeri 5 Menara lebih beragam. Jika pada novel Sang Pemimpi, pergerakan impian tokoh lebih mengarah pada peradaban Barat, pergerakan impian tokoh pada novel Negeri 5 Menara tidak hanya tertuju peradaban Barat, tetapi juga peradaban Timur (Islam). Hal ini tampaknya dilatarbelakangi kehidupan pesantren tempat para tokoh berasal yang memadukan ilmu pengetahuan Barat dan Timur sehingga terjadi persebaran kecenderungan untuk melanjutkan pendidikan. Namun, kecenderungan tokoh Alif untuk melanjutkan pendidikan ke Amerika memunculkan wacana bahwa pendidikan Barat dianggap lebih unggul. Hal ini sejalan dengan apa yang disampaikan oleh Wahid (dalam Tanter dan Young, 1989: 20) bahwa ada kecenderungan keluarga muslim untuk memasukkan anak mereka ke sekolah berpendidikan Barat sebagai dampak dari persentuhan kultural dengan peradaban Barat.

Sementara itu, pada novel Ayat-Ayat Cinta karya Habiburrahaman El-Syirazi (2004), impian tentang pendidikan lebih terarah pada pendidikan yang berkiblat pada peradaban Timur (Islam). Hal ini ditunjukkan melalui pemilihan Universitas Al Azhar, Kairo, sebagai setting tempat Fahri, tokoh utamanya, melanjutkan studi. Universitas Kairo sebagai universitas tertua di dalam peradaban Timur (Islam) beroposisi dengan Universitas Sorbonne, Paris, sebagai pusat peradaban Barat. Dengan menunjukkan keunggulan-keung- gulan yang didapatkan pengarang selama melakukan studinya di Universitas Kairo, hal itu semakin menguatkan wacana tentang pendidikan dari peradaban Timur sebagai peradaban unggul.

Dari paparan di atas dapat disimpulkan bahwa pada novel populer tahun 2000-an, impian perubahan kelas melalui pendidikan merupakan wacana dominan yang ada pada setiap novel tahun 2000-an. Impian ini biasanya berkaitan dengan mobilitas vertikal melalui jalur pendidikan yang dilakukan golongan anak muda dalam upaya mereka menjadikan kehidupan di masa yang akan datang menjadi lebih baik.

\section{Subjek Anak Muda sebagai Pembawa Impian}

Berdasarkan paparan sebelumnya, cerita pada novel populer tahun 2000-an pada umumnya dibawakan tokoh anak muda biasa. Hal ini menguatkan bahwa budaya populer tersebut pada dasarnya memang berasal dari, untuk, dan oleh orang biasa (Heryanto, 2012: 10) yang pada zaman modern ini kemudian dibantu oleh teknologi produksi dan distribusi sebagai bagian dari masyarakat industrial. Dicontohkan Heryanto, Inul Daratista merupakan gambaran tokoh yang merepresentasikan masyarakat awam. Ia memiliki kemampuan bernyanyi dan bergoyang yang sangat mungkin dimiliki oleh penyanyi lainnya. Namun, melalui media, Inul dibentuk dan diproduksi menjadi sosok idola yang lahir dari masyarakat itu sendiri. Heryanto menunjukkan kemampuan media untuk memproduksi makna tersebut sehingga ia menjadi representasi idola masyarakat. Inul memberikan makna bahwa impian itu dapat diraih meskipun dalam kenyataannya hanya ada satu atau dua orang yang mampu mewujudkan impian tersebut. Demikian pula yang terjadi pada realitas teks novel populer tahun 2000-an yang menjadikan orang-orang biasa sebagai sosok idola baru masyarakat pembaca. 
Tokoh-tokoh anak muda yang muncul di dalam novel populer tahun 2000-an merupakan anak muda yang berasal dari kelas pinggiran. Anak muda ini adalah anak muda yang lahir dari daerah pinggiran yang selama ini tidak tersuarakan dalam wacana novel populer pada era sebelumnya, seperti yang tampak pada era 70-an dan 80-an. Pada umumnya, anak muda yang muncul pada novel populer sebelumnya adalah anak muda yang berasal dari kelas sosial menengah atas dan berasal dari jantung peradaban Indonesia seperti Jakarta, Bandung, dan Yogyakarta. Hal tersebut tampak pada novel Lupus: Tangkaplah Daku Kau Kujitak karya Hilman Hariwijaya (1986), Ali Topan Anak Jalanan karya Teguh Esha (1977), Cintaku di Kampus Biru karya Ashadi Siregar (1974), atau Gita Cinta dari SMA karya Eddy D. Iskandar (1978) yang menunjukkan gambaran betapa wacana dominan tentang anak muda adalah wacana yang berasal dari pusat-pusat kota di Indonesia. Dengan demikian, kemunculan anak muda yang berasal dari daerah pinggiran dan dari kelas sosial bawah ini menjadi sebuah suara berbeda yang berpotensi menggantikan suara dominan tentang anak muda dalam wacana novel populer Indonesia.

Munculnya suara berbeda tentang anak muda dapat dilihat pada novel Sang Pemimpi (2005). Ikal adalah sosok anak muda impian. Latar belakangnya terlahir dari keluarga miskin dan dibesarkan dalam masyarakat Melayu Belitong yang sangat terbelakang secara pendidikan. Namun, keterbelakangan masyarakat Melayu tersebut membuat Ikal menjadi istimewa karena keberadaannya yang berbeda dengan teman-teman sebayanya yang beretnis Melayu. Sedari kecil, ia sudah harus melupakan masa depannya dengan dibiasakan melakukan pekerjaan kasar. Hal itu sebagaimana digambarkan dalam kutipan di bawah ini.
Anak-anak Melayu ini paling miris nasibnya.... Menjadi pendulang, nelayan jermal, dan kulit pasir, berarti mengucapkan selamat tinggal pada Tut Wuri Handayani.... Aku, Arai, dan Jimbron, memilih sebuah pekerjaan yang sangat bergengsi sebagai tukang pikul ikan di dermaga. Profesi yang sangat elite itu disebut kuli ngambat. Kami dengan sengaja memilih profesi itu karena memungkinkan untuk dikerjakan sambil sekolah (Hirata, 2005: 56-57).

Teks di atas menunjukkan sebuah wacana baru tentang anak muda, yakni tentang keberadaan anak muda di ruang pinggiran yang memiliki keterbatasan ekonomi, tetapi tidak pantang menyerah dengan kondisi yang dihadapinya. Bekerja bagi anak muda ini bukanlah jalan untuk memenuhi kebutuhan sehari-harinya, tetapi bekerja menjadi jalan untuk menyelamatkan hidup dan tetap menghidupkan impiannya. Dua aktivitas yang dilakoni Ikal - sekolah dan bekerja - memperlihatkan dirinya berbeda dengan yang lain: bersekolah dan bekerja, dan di dalamnya ada impian besar yang tidak dimiliki oleh teman sebayanya pada umumnya.

Sebagai tokoh utama, Ikal memenuhi persyaratan sebagai sosok anak muda yang diidolakan pembaca. Ia berasal dari keluarga miskin yang berayah seorang pekerja kasar di PT Timah yang perlahan kolaps. Berlatar pendidikan dari sebuah sekolah SD yang hampir rubuh, kemudian melanjutkan SMA di kota kecamatan yang berjarak $30 \mathrm{~km}$ dari kampungnya, dengan tinggal di sebuah kamar sempit berukuran $2 \times 2$ meter, yang dibagi bertiga bersama temantemannya. Ia membiayai hidupnya dengan cara bekerja sebagai tukang pikul ikan di pagi hari. Ia kemudian melanjutkan impian ke Pulau Jawa, sampai akhirnya diterima di Universitas Sorbonne, lambang puncak dari institusi ilmu pengetahuan. Maka, ia menjadi sosok yang lengkap sebagai sosok idola baru bagi pembaca. Ia mewakili masyarakat biasa, tetapi pada satu sisi, ia tidak sama dengan masyarakat biasa. Jadi, dalam 
waktu yang bersamaan sosok Ikal mewakili gambaran masyarakat pembaca, sekaligus menunjukkan perbedaannya dengan masyarakat pembaca. Posisi ini membuat tokoh Ikal berada dalam ruang yang mencoba memediasi antara struktur dan agensi (subjek).

Meskipun lahir dari masyarakat Melayu di sebuah kampung yang miskin, Ikal menunjukkan perbedaannya dari lingkungan masyarakatnya. Kecerdasannya yang di atas rata-rata membuat ia sangat menonjol di kalangan teman-temannya, menjadikan ayahnya juga menjadi sangat dikenal dan dihargai di sekolah. Impiannya yang ingin menjejak dan mengecap ilmu pengetahuan Eropa membuatnya tidak henti untuk berupaya untuk mewujudkannya. Nalar tokoh dipengaruhi oleh semangat modernisme yang menjadikan ilmu pengetahuan sebagai sebuah logos. Semangat modernisme ini pula yang membawa perubahan besar dalam kehidupan manusia terutama terkait dengan pencarian hakikat kemanusiaan (Adian, 2002: 10). Kesadaran rasionya sebagai pusat kekuatan mampu mengalahkan emosi-emosi pesimistis yang sempat membayanginya dalam mencapai tujuannya tersebut, sebagaimana kutipan di bawah ini.

Mendahului nasib! Dua kata yang menjawab kekeliruanku melihat arah hidupku. Pesimistis tak lebih dari sikap takabur mendahului nasib (Hirata, 2005: 143).

Kutipan teks di atas menunjukkan adanya kesadaran subjek. Kembalinya kesadaran subjek menunjukkan kekuatan agensi berhadapan dengan struktur sosial. Kesadaran narator atas potensi subjek mengalahkan ketakutan-ketakutannya saat berhadapan dengan realitas. Dengan demikian, sosok idola yang terepresentasikan pada tokoh Ikal adalah sosok anak muda yang memiliki semangat yang tinggi disertai kesadaran subjek sehingga berani menghadapi struktur sosial yang kadang-kadang membelenggu subjek tersebut.
Teks novel ini paralel dengan pengalaman kultural pengarangnya, Andrea Hirata. Kehidupan ekonomi keluarganya dan realitas Pulau Belitong yang penuh dengan keterbatasan dan minim fasilitas diakui oleh Hirata menjadi motivasi hidup terbesar pada dirinya. Pengalaman kulturalnya yang kaya menjadi titik pijak bagi Hirata untuk menyebarkan pesan didaktis melalui teks novel yang dibuatnya karena bagi Andrea Hirata, seorang penulis yang sukses adalah seorang penulis yang mampu menggerakkan pembacanya untuk melakukan hal-hal yang luhur. Dengan demikian, pengalaman kultural dan visi kepengarangan Hirata saling bertalian yang terepresentasi dalam karyanya. Hal ini sejalan dengan pandangan Pradopo (1995: 114), bahwa karya sastra (novel) tidak bisa dilepaskan dari intensi pengarang.

Selanjutnya, suara yang berbeda juga terlihat pada novel Negeri 5 Menara (2009). Tokoh utamanya, Alif memiliki gambaran tipikal anak muda yang hampir sama dengan Ikal. Ia juga berasal dari keluarga biasabiasa saja, yang berasal dari sebuah daerah yang jauh dari kota. Keudikan Alif terlihat ketika ia menyentuh peradaban yang lebih maju, yaitu Pulau Jawa. Dari seorang anak udik, bermimpi untuk melanjutkan ke sekolah yang dianggap memiliki level yang lebih tinggi, Alif kemudian melompatkan impiannya untuk meraih pendidikan tinggi di luar negeri. Sebagai anak muda yang berada di ruang pinggiran, Alif mampu memelihara impiannya dengan tetap mempertahankan impiannya tersebut dan berjuang melawan hambatan-hambatan yang datang dari luar, juga melawan hambatan dari dalam dirinya sendiri (Fuadi, 2009: 313).

Gambaran tentang Alif di atas merupakan representasi dari anak-anak muda dari wilayah pinggiran yang di dalam novel populer sangat jarang disuarakan. Yang juga penting untuk dilihat adalah upaya pengarangnya, Ahmad Fuadi, un- 
tuk menyuarakan pendidikan pesantren di dalam teks novel populer patut untuk diapresiasi. Sebagaimana diketahui, pendidikan pesantren dianggap sebagai pendidikan yang tidak memiliki keunggulan dalam ilmu pengetahuan umum. Konsentrasi pesantren yang lebih banyak fokus pada pendidikan agama dianggap menjadi titik kelemahan dalam pendidikan umum sehingga pesantren dianggap bukanlah lembaga yang prestisius yang mampu mencetak sumber daya manusia yang andal. Rendahnya penilaian masyarakat terhadap pesantren juga terungkap dari pandangan masyarakat di dalam teks yang menganggap bahwa sekolah agama hanya merupakan sekolah penampungan bagi anak-anak yang bermasalah. Penggambaran tentang perjuangan Alif di sekolah pesantren dan capaian yang diraihnya, mulai dari bekerja di majalah berita nasional sampai bersekolah ke luar negeri, memberikan suara yang berbeda tentang kehidupan dunia pesantren yang jarang tersentuh dalam wacana novel populer.

Selanjutnya, problematika yang dihadapi Alif menjadikannya tampak sebagai sosok anak muda yang manusiawi. Hal ini mendekatkan sosok Alif dengan masyarakat pembaca. Artinya, ia adalah anak muda yang memiliki tipikal umum anggota masyarakat, tetapi di saat yang bersamaan ia menunjukkan perbedaannya dengan masyarakat umum. Perbedaan tersebut terlihat dari keteguhannya menjalani kehidupan pesantren yang sangat disiplin dan terkontrol demi meraih impian-impiannya. Dengan demikian, Fuadi sebagai pengarang ingin menunjukkan bahwa anak muda yang layak diidolakan adalah anak muda yang memahami kemampuan dirinya dengan baik dan terus mengembangkan kemampuan tersebut dengan disiplin.

Selanjutnya, tokoh Fahri dalam novel Ayat-Ayat Cinta (2004) juga ditampilkan sebagai anak muda biasa. Ia digambarkan se- bagai anak santri yang berasal dari keluarga miskin. Kemudian, ia mampu meneruskan pendidikannya di Kairo, dengan berbekal bantuan dari sawah kakeknya dan menjalankan dengan secara konsisten dan disiplin terhadap tujuan-tujuan hidupnya. Berbekal kecerdasan, kesalehan, dan keluasanilmuagamanya yang diakui oleh banyak orang, satu persatu impian-impian dalam kehidupannya dapat diraihnya. Salah satu kisah monumental dalam alur cerita AyatAyat Cinta adalah ketika kepintaran, kesalehan, dan keluasan ilmunya itu menarik perhatian seorang perempuan cantik yang kaya raya yang membawa Fahri ke dalam kehidupan kelas atas yang tidak dapat dijangkau oleh teman-temannya. Hal tersebut membawanya ke dalam posisi yang berbeda dibandingkan dengan teman-temannya dan kehidupan riil masyarakat pembaca. Pada titik itulah, sosok Fahri disuarakan teks sebagai anak muda yang patut diidolakan oleh masyarakat pembaca karena ia merepresentasikan gambaran masyarakat pada umumnya. Akan tetapi, pada saat yang bersamaan ia melampaui batas-batas struktur tersebut. Dengan bangunan seperti di atas, El-Syirazi sebagai pengarang ingin menunjukkan bahwa sosok anak muda yang layak diidolakan adalah anak muda berdisiplin dengan impian hidupnya dan yang memelihara dirinya dengan ajaran agama dan berpegang teguh terhadap ajaran tersebut.

Dari paparan di atas, dapat disimpulkan bahwa ketiga novel tersebut memiliki formula yang hampir sama dalam menghadirkan anak muda. Tokoh-tokoh tersebut mewakili gambaran pembaca pada umumnya, yang mempunyai kesadaran subjektif yang diwujudkan dalam bentuk impian-impian, tetapi tidak cukup memiliki keberanian untuk meraihnya karena belenggu struktur sosial yang melampaui subjek tersebut. Ikal, Alif, dan Fahri adalah gambaran sosok anak muda pada umum- 
nya yang berasal dari kalangan masyarakat biasa. Akan tetapi, mereka dikontruksi menjadi anak muda yang berbeda dari anak muda Indonesia pada umumnya karena mampu melampaui struktur sosial tersebut dan menunjukkan agensi mereka dengan cara memiliki keberanian untuk mewujudkan impian-impian mereka.

\section{Nilai-Nilai Individual sebagai Kekuatan pada Diri Anak Muda}

Impian dibutuhkan dalam menguji nilai-nilai kesungguhan pada diri tokoh. Teks novel yang telah dibahas di atas menunjukkan impian-impian yang kuat dari tokoh yang coba diwujudkan melalui kesungguhan untuk mencapainya. Nilai kesungguhan meraih impian pada tokoh-tokoh anak muda pada novel populer tahun 2000-an ini menjadi kekuatan individual yang dimiliki oleh anak muda pada periode ini. Sikap bermain-bermain dan bersenang-bersenang dalam kehidupan anak muda, seperti yang ditunjukkan pada novel populer periode sebelumnya, tidak begitu tampak pada novel-novel ini. Yang dimunculkan adalah anak-anak muda yang menjaga konsistensi mereka pada impian yang mereka bangun.

Kesungguhan untuk mencapai impian ditunjukkan dalam Negeri 5 Menara (2009) melalui pepatah dalam bahasa Arab man jadda wajada 'barangsiapa bersungguhsungguh pasti akan mendapatkan hasil' artinya yang terus diulang-ulang di dalam teks novel. Kesungguhan meraih impian ini semakin mengental dengan latar belakang tokoh Alif yang secara ekonomi berasal dari kelas bawah.

Latar belakang pengarang semakin menguatkan nilai yang dikandung oleh teks novel tersebut. Ahmad Fuadi berasal dari keluarga yang sederhana. Ia melanjutkan ke sekolah pesantren di Jawa, kemudian melanjutkan sekolah di perguruan tinggi negeri di Jawa Barat, sampai akhirnya dapat melanjutkan studi di Amerika Seri- kat dan Inggris dengan bantuan beasiswa. Latar belakang pengarang beserta perjuangannya dalam usaha mewujudkan impian semakin menguatkan bahwa kesungguhan dalam mencapai impian merupakan hal yang mutlak diperlukan bagi anak muda.

Alif tidak digambarkan sebagai murid yang paling pintar di sekolah. Ia, bahkan, sering merasa iri dengan teman-temannya yang memiliki kemampuan hafalan yang sangat baik. Akan tetapi, Alif mengetahui kelebihan utama pada dirinya, yaitu kemampuan bahasa, sehingga ia terus mengembangkan kelebihannya tersebut. Dengan mengetahui kelebihannya, narator sedang menunjukkan bahwa tokoh memahami dirinya dengan baik sehingga dengan pemahaman yang baik terhadap diri sendiri, ia akan menemukan dirinya.

Seperti telah dijelaskan sebelumnya, Pesantren adalah "kawah candradimuka" bagi Alif dalam proses penggodokan dirinya untuk mencapai impiannya. Hal itu telah dijelaskan di paparan awal bahwa Pesantren Madani yang relatif steril dari karut-marut realitas sosial masyarakat seperti yang tampak pada novel Sang Pemimpi (2005) membuat jalan Alif lebih lempang untuk sampai pada impiannya. Sterilisasi yang dijalankan melalui mekanisme kontrol oleh senior-senior pengawas menjadi bagian yang sulit dalam perjalanan hidup Alif di pesantren meskipun kontrol tersebut semakin mengendor sejalan dengan adaptasi yang dapat dilakukan Alif terhadap sistem tersebut.

Hambatan terbesar Alif untuk tetap bertahan dalam lingkungan pendidikan pesantren adalah dengan dimunculkannya tokoh Randai. Surat dari Randai, teman Alif semasa di SMP, yang datang secara rutin menyambanginya, sempat membuat pendiriannya labil. Pendiriannya untuk berada dalam ruang-ruang idealitas mengalami benturan-benturan yang membuat Alif menjadi goyah, seperti dikemukakan 
dalam kutipan berikut.

Akhirnya pertanyaan itu meledak juga keluar: bagaimana kalau aku keluar dari PM, sekarang juga, agar aku bisa mengejar mimpi seperti Randai. Menjadi mahasiswa dan bukan di jalur pelajaran agama. Tapi artinya aku akan jadi orang yang kalah, karena pulang ketika perang belum usai. Aku tidak menyelesaikan apa yang aku mulai. Apa kata alam semesta? (Fuadi, 2009: 313).

Ketangguhan invidualitas sebagai anak muda justru diuji dengan adanya hambatan-hambatan yang datang dari luar. Dalam konteks ini, pengarang mengontruksi Alif sebagai anak muda yang memiliki kekuatan individual dan kemandirian sikap sehingga mampu melewati ujian-ujian eksternal tersebut.

Tokoh Ikal pada Sang Pemimpi (2005) memiliki tipikal yang sama dengan tokoh Alif pada Negeri 5 Menara (2009). Ikal juga digambarkan berasal dari sebuah keluarga kelas bawah, baik secara sosial maupun ekonomi. Untuk mencapai impiannya tersebut, Ikal digambarkan melalui proses yang lebih rumit dibandingkan dengan Alif. Tokoh Alif diuntungkan dengan sistem pendidikan di pesantren yang telah memiliki pola pendidikan yang jelas, yang dibangun dengan disiplin yang ketat. Alif juga diuntungkan oleh relasi pesentren yang kuat dengan pihak-pihak di luar pesantren, termasuk dengan dunia internasional. Sementara itu, Ikal tidak berada dalam kondisi seperti itu. Sekolah Ikal berada di sebuah kota kecil dan merupakan sebuah sekolah negeri, yang tentu saja tidak menerapkan sistem yang terpola dan terkontrol seperti pada sekolah Alif.

Dengan lingkungan sosial yang lebih labil, Ikal dihadapkan pada kekonsistenannya agar tetap membangun impiannya sebagai individu (agensi) atau ia hanya akan kembali menjadi bagian dari sekumpulan massa. Hal itu seperti dikemukakan dalam kutipan berikut.

Hawa positif dalam tubuhku menguap dibawa hasutan-hasutan yang melemahkan diriku sendiri. Untuk apa aku memecahkan kepalaku mempelajari teorema bilangan tak berhingga jika yang tak berhingga bagiku adalah kemungkinan tak mampu melanjutkan sekolah setelah SMA? Buat apa aku bersitegang urat leher, berdebat di kelas soal geometri jika yang tersisa untukku hanya sebuah kamar kontrakan sempit 2 x 2 meter di dermaga? (Hirata, 2005: 134).

Kutipan di atas menunjukkan bahwa realitas sosial yang melingkupi tokoh menjadi faktor yang mampu melemahkan dirinya sebagai anak muda. Dengan demikian, tarikmenarik antara kekuatan tokoh sebagai individu dan sebagai bagian dari masyarakat menjadi penentu kualitas diri Ikal.

Kesungguhan Ikal dalam mewujudkan impiannya terlihat dari usahanya yang kuat melawan ketidakberdayaan ekonomi keluarganya dan ketidakberdayaan sosial. Dari desanya, hanya Ikal, Arai, dan Jimbron yang berhasil melanjutkan ke sekolah SMA. Kesungguhan pula yang membuat Ikal dan Arai dapat melanjutkan sekolah ke Jawa, sampai kemudian dapat menembus ketatnya persaingan untuk mendapatkan beasiswa studi ke luar negeri. Di lain sisi, Jimbron tidak dapat mengikuti jejak Ikal. Ia hanya sampai selesai SMA dan memutuskan berhenti untuk mengejar impiannya. Prestasi sekolah dan mentalitasnya yang tidak kuat menjadi penanda atas kesulitannya untuk mengejar impian tersebut. Dengan demikian, pola oposisi biner dimunculkan pada tokoh Ikal dan Jimbron, temannya, secara tidak langsung menghadirkan ketangguhan individualitas Ikal sehingga ia mampu menghadapi hambatan-hambatan dari eskternal dirinya.

Dengan kesungguhan mewujudkan impian besar itu, Ikal juga harus berkorban besar: berpisah dengan keluarga, mengontrak kamar bersama-sama tanpa kehadiran orang tua masing-masing, dan menjadi pekerja kasar di pelabuhan setiap hari sebelum pergi ke sekolah. Tjandraningsih (dalam Iryani \& Priyarsono, 2013: 178) mengatakan ketika anak-anak tidak mempunyai ke- 
sempatan untuk bersekolah, maka pilihan hidupnya hanya dua, yaitu: masuk angkatan kerja atau tidak. Pernyataan ini menunjukkan bahwa tidak ada ruang pilihan yang banyak ketika seorang anak mengalami pemutusan sekolah karena keterbatasan ekonomi. Dalam teks novel Sang Pemimpi juga ditunjukkan bagaimana anak-anak Melayu itu harus berhenti sekolah dan bekerja serabutan untuk memenuhi kebutuhan hidup mereka. Dengan konstruksi teks seperti di atas, pengarang berusaha menunjukkan bahwa Ikal sebagai anak muda memiliki kekuatan individu yang melampaui usia anak muda sebayanya. Dengan cara itulah, wacana tentang kekuatan indivual anak muda dibangun.

Sementara itu, Fahri memperlihatkan kesungguhannya dalam menggapai tujuannya melalui upaya kerasnya dalam mendisiplinkan tubuhnya demi mencapai impiannya, seperti dikemukakan dalam kutipan berikut..

Yang kutempel memang arah hidup sepuluh tahun ke depan. Target-target yang harus kudapat dan apa yang harus kulakukan. Lalu peta hidup satu tahun ini. Ku tempel di depan tempat belajar untuk penyemangat. Dan memang kutulis dengan bahasa Arab (El-Syirazi, 2004: 142).

Kekejaman pada diri sendiri untuk bekerja keras menampakkan hasilnya. Hari Jumat terjemahan selesai. Tinggal menunggu diedit saja. Proposal tesis juga selesai, siap untuk diajukan ke tim penilai. Jika layak nanti pihak fakultas akan mencarikan promotor yang sesuai (El-Syirazi, 2004: 161).

Fahri dengan sadar melakukan pendisiplinan terhadap dirinya dengan mengabaikan kesenangan sebagai anak muda yang mungkin dilakukan bersama temannya. Kedisiplinan terhadap dirinya tersebut membuahkan hasil berupa impian-impian masa depan yang satu demi satu terwujud.

Ujian terbesar yang dialami oleh Fahri adalah ujian yang berasal dari luar dirinya, ketika ia dituduh memperkosa Noura, yang membuatnya merasakan penjara Mesir.
Fahri mengalami kesulitan meredam amarah dan kecemasannya ketika ia digeledah oleh polisi Mesir di kontrakannya. Pada bagian ini, Fahri digambarkan menghadapi kendala psikologis dan emosional yang cukup berat sehingga Fahri dimunculkan dengan karakter yang tampak lebih manusiawi. Ia menunjukkan perubahan emosinya, ketakutannya, ketidakberdayaannya serta kerapuhannya ketika menghadapi tekanan di luar batas kemampuannya, seperti dikemukakan dalam kutipan berikut.

Sungguh perlakuan yang sangat tidak manusiawi. Aku merasakan penghinaan yang luar bisa. Aku belum pernah merasakan diriku dihina dan kehormatanku dinistakan senista itu. Aku lebih suka dirajam daripada dihina seperti itu. Jika kau sampai terlihat mengucurkan air mata, maka ketiga setan itu akan semakin gila tertawanya. Aku merintih dalam hati. Batinku menangis sejadijadinya memohon keadilan kepada Allah. Agar mereka diganjar atas kekurangajaran mereka (El-Syirazi, 2004: 310-311).

Hambatan ini pada akhirnya dapat dilewati Fahri dengan keteguhan dan kesabarannya menghadapi persoalan hidup tersebut. Ia diselamatkan dari tuntutan perkosaan yang dialamatkan kepadanya. Berbagai kesaksian yang meringankannya membuat Fahri dinyatakan bebas. Dengan demikian, bagian peristiwa tersebut sengaja dimunculkan dalam teks untuk menunjukkan kekuatan Fahri sebagai individu.

Dari paparan di atas, dapat disimpulkan bahwa anak muda yang dikontruksi dalam novel populer tahun 2000-an adalah anak muda yang memiliki kekuatan agensi sehingga mampu melampaui batas standar yang diakui dalam struktur masyarakat atau mampu melampaui norma-norma konvensional yang berlaku di dalam masyarakat tersebut. Hal ini menjadi suara baru tentang kehidupan anak muda yang selama ini selalu diidentikkan dengan budaya instan. Anak muda yang disuarakan dalan novel-novel populer di atas adalah anak muda yang menjalani kehidupan dengan penuh proses dan meyakini dengan penuh 
kesadaran bahwa kekuatan terbesar adalah kekuatan dirinya sendiri. Anak muda yang disuarakan dalan novel populer tahun 2000an adalah anak muda yang bukan lahir dari fasilitas dan kemudahan proses seperti yang diperlihatkan oleh ajang pencarian bakat yang diproduksi oleh media massa pada masa kini. Dengan demikian, pada novelnovel populer terdapat wacana kesadaran agensi yang kuat terhadap struktur sosial. Hal ini ditunjukkan melalui kekuatan individual tokoh anak muda yang berani berhadapan dengan struktur sosial dalam upaya mewujudkan impian mereka.

\section{SIMPULAN}

Novel populer tahun 2000-an menampilkan sosok anak muda sebagai tokoh utama yang digambarkan sebagai anak muda yang keluar dari citra kelas dominan. Anak muda laki-laki yang ditampilkan adalah anak muda yang berasal dari kelas sosial ekonomi bawah dan dari daerah pinggiran.

Gambaran anak muda dalam novel populer tahun 2000-an ini berbeda dengan gambaran umum yang ditampilkan pada novel era sebelumnya yang biasanya lebih memprioritaskan aspek kesenangan dan kehidupan yang ada dalam ruang dan waktu saat itu. Anak muda yang digambarkan pada novel populer tahun 2000-an adalah anak muda yang mandiri, pekerja keras, mempunyai impian, dan mempunyai keberanian, dan kekuatan untuk memperjuangkan impiannya. Mereka mewakili gambaran anak muda yang mempunyai kesadaran agensi yang diwujudkan dalam bentuk impian-impian, tetapi tidak cukup memiliki keberanian untuk meraihnya karena belenggu struktur sosial yang melampaui subjek tersebut.

Konstruksi budaya yang dibangun di dalam teks berelasi dengan realitas sosial ketika teks novel tersebut ditulis, dan pengarang sebagai bagian dari sistem sosial tersebut. Dari pola relasi oposisi biner yang dibangun di dalam teks, didapatkan simpulan bahwa impian menjadi wacana dominan pada novel populer tahun 2000-an, sedangkan anak muda yang berada di luar imaji populer masyarakat didaulat sebagai pengusung impian tersebut. Tokoh yang dihadirkan adalah anak muda yang dapat menunjukkan agensinya dengan mengatasi struktur sosial.

Impian anak muda pada novel popular sangat berorientasi pada mobilitas vertikal, yaitu naiknya kelas sosial mereka ke kelas yang lebih tinggi, yang dilakukan melalui jalur pendidikan. Melalui keberanian bermimpi dan meraih impiannya tersebut, tokoh anak muda di dalam novel populer tahun tahun 2000-an dikonstruksi menjadi anak muda yang mampu mengatasi struktur sosial. Pilihan memunculkan anak muda di luar arus utama (main stream) tersebut menguatkan pesan bahwa impian dapat diraih oleh siapapun dari kelas manapun sepanjang ada keberanian dan upaya untuk meraih impian tersebut.

Kemunculan anak muda dari wilayah pinggiran yang ditampilkan pada novel popular memberi implikasi terhadap munculnya suara-suara lokal yang selama ini tidak menjadi arus utama di dalam novel populer, seperti munculnya etnis di luar Jawa, kultur pendidikan pesantren, dan etos kerja anak muda dari daerah. Dengan demikian, novel populer tahun 2000-an juga menawarkan nilai-nilai baru dengan menghadirkan suara-suara lokal sehingga konstruksi budaya anak muda yang muncul di dalam novel populer menjadi lebih beragam.

\section{Daftar Pustaka}

Adian, D. G. (2002). Menyoal Objektivisme Ilmu Pengetahuan. Jakarta: Teraju.

Iryani, B, S. dan D.S. Priyarsono. (2013). Eksploitasi terhadap Anak yang Bekerja di Indonesia - Exploitation of Working Children in Indonesia. E- 
konomi dan Pembangunan Indonesia, 13 (2), $177-195$.

El-Syirazi, H. (2004). Ayat-Ayat Cinta. Jakarta: Republika Press.

Faruk. (2012). Metode Penelitian Sastra. Yogyakarta: Pustaka Pelajar.

Fuadi, A. (2009). Negeri 5 Menara. Jakarta: Gramedia Pustaka Utama.

Hanif, W. dan Y. A. Piliang. (2016). Kitsch dalam Iklan TV Komersial dan Selera Konsumer Indonesia. Panggung, 26 (3), $323-335$.

Herwanto, A. (2005). “Budaya, Struktur, dan Pelaku" dalam Teori-Teori Kebudayaan (editor: Mudji Sutrisno dan Hendar Putranto). Yogyakarta: Kanisius.

Hirata, A. (2005). Sang Pemimpi. Yogyakarta: Bentang Pustaka.

Iskandar, A., C. Sobarna, D. Mulyana, dan \& Y. Y. Risagarniwa. (2014). Kajian Budaya Fotografi Potrait dalam Wacana Personalitas. Panggung, 24 (3), $308-315$.

O’Donnel, K. (2009). Postmodernisme. Yogyakarta: Kanisius.

Piliang, Y. A (1999). Hiper-Realitas Kebudayaan. Yogyakarta: LkiS.

--. (2003). Hipersemiotika: Tafsir Cultural Studies atas Matinya Makna. Yogyakarta: Jalasutra.
Pradopo, R. D. (1995). Beberapa Teori Sastra, Metode Kritik, dan Penerapannya. Yogyakarta: Pustaka Pelajar.

Ratna, N. K. (2006). Teori, Metode, dan Teknik Penelitian Sastra. Yogyakarta; Pustaka Pelajar.

--. (2007). Sastra dan Cultural Studies: Representasi Fiksi dan Fakta. Yogyakarta: Pustaka Pelajar.

Saidi, A. I. (2008). Narasi Simbolik Seni Rupa Kontemporer Indonesia. Yogyakarta: IsacBook.

Saidi, A. I. dan A. E. Budiwaspada. (2015). Visualisasi dan Transformasi Kebertubuhan dalam Film Animasi Planes (Ke Arah Pembentukan Mitos Baru). Panggung, 25 (4), 326 - 341.

Sen, K. dan D. T. Hill. (2001). Media, Budaya, dan Politik di Indonesia. Jakarta: ISAI.

Storey, J. (2007). Cultural studies dan Kajian Budaya Pop (pen. Laily Rahmawati). Yogyakarta: Jalasutra.

Sumardjo, J. (1982). Novel Populer Indonesia. Bandung: Nur Cahaya.

Tanter, R. dan K. Young (Eds.). (1989). Politik Kelas Menengah Indonesia. Jakarta: LP3ES.

Teeuw, A. (2003). Sastra dan Ilmu Sastra. Jakarta: Pustaka Jaya. 